\title{
Incidence and risk of hepatic toxicities associated with anaplastic lymphoma kinase inhibitors in the treatment of non-small-cell lung cancer: a systematic review and meta-analysis
}

\author{
Bing Liu ${ }^{1}$, Maoxi Yuan ${ }^{1}$, Yi Sun ${ }^{1}$, Ziming Cheng ${ }^{1}$, Zaiyong Zhang ${ }^{1}$, Shizheng Hou ${ }^{1}$, \\ Xiangdong Wang ${ }^{1}$ and Jingfeng Liu ${ }^{1}$ \\ ${ }^{1}$ Department of Thoracic Surgery, Linyi Central Hospital, Yishui 276400, Shandong Province, China \\ Correspondence to: Bing Liu, email: liubing20170101@126.com
}

Keywords: ALK TKIs, liver toxicity, lung cancer, meta-analysis

Received: May 27, 2017 Accepted: July 26, $2017 \quad$ Published: December 16, 2017

Copyright: Liu et al. This is an open-access article distributed under the terms of the Creative Commons Attribution License 3.0 (CC BY 3.0), which permits unrestricted use, distribution, and reproduction in any medium, provided the original author and source are credited.

\section{ABSTRACT}

Background: Two anaplastic lymphoma kinase (ALK)-tyrosine kinase inhibitors (-TKIs) have been approved for the treatment of patients with ALK-rearranged (ALKpositive) advanced non-small cell lung cancer (NSCLC). Severe hepatotoxicity has been observed in several clinical studies. We aim to assess the incidence and risk of liver toxicity with these drugs by a systematic review and meta-analysis of clinical trials.

Materials and Methods: The databases of PubMed, Web of Science and abstracts presented at oncology conferences' proceedings were searched for relevant studies from January 2000 to January 2017. Summary incidence rates, relative risks (RRs), and $\mathbf{9 5 \%}$ confidence intervals (CIs) were calculated by using either random effects or fixed effect models.

Results: A total of 1,908 patients from 10 clinical trials were included. The incidences of all-grade aspartate aminotransferase (AST) and alanine transaminase (ALT) elevation were 25.2\% (95\% CI 17.7-34.7\%), and 26.0\% (95\% CI 17.8-36.3\%), respectively. The incidences of high-grade (grade 3 and 4) AST and ALT elevation were 7.0\% (95\% CI: 5.4-9.0\%), and 9.9\% (95\%CI: 5.6-16.7\%), respectively. Sub-group analysis according to ALK-TKIs showed that the incidence of liver toxicities associated with ceritinib was higher than that of crizotinib and alectinib. In comparison with chemotherapy, ALK-TKIs significantly increased the risk of developing all-grade and high-grade AST elevation (RR, 2.30, 95\%CI: 1.87-2.83, $p<0.001 ;$ RR 10.14, 95\% CI: 3.9-26.39, $p<0.001$ ) and ALT elevation (RR 2.37, 95\%CI: 1.97-2.86, $p<0.001$; RR 7.34, 95\% CI: 3.95-13.63, $p<0.001$ ), respectively.

Conclusions: The use of ALK-TKIs significantly increases the risk of developing all-grade and high-grade liver toxicities in lung cancer patients.

\section{INTRODUCTION}

Lung cancer is the most common cancer and the leading cancer-related deaths around the worldwide [1]. The majority of lung cancer cases (approximately 80-85\%) are diagnosed as non-small-cell lung cancer (NSCLC), including squamous carcinoma, adenocarcinoma and large cell carcinoma [2]. Although platinum-based doublets chemotherapy remains the standard treatment for advanced NSCLC with good performance status, a variety of novel molecular targeted agents have been introduced into clinical practice due to major progress in the understanding of the pathogenesis of NSCLC, which blocking dysregulated signaling pathways [3-5]. signaling pathway, implicating in the cancer cell proliferation and survival, is the first oncogenic drivers to be found in lung cancer [6]. Indeed, published data from clinical trials has shown that EGFR-tyrosine kinase inhibitors (TKIs) are superior to conventional chemotherapy in advanced NSCLC patients presented with EGFR mutation [7-10]. Recently, NSCLC patients harboring an anaplastic lymphoma kinase (ALK) -rearrangement represent the 
second oncogene addiction to be identified in NSCLC $[11,12]$. Rearrangements of the ALK gene are present in in several human cancers and occur in approximately $5 \%$ of advanced NSCLC. Specific ALK-TKIs have been developed during the past decade. Currently, two ALKTKIs, crizotinib and ceritinib, have been approved in many countries worldwide for the treatment of advanced/ metastatic ALK-rearranged NSCLC patients [13, 14].

Generally, the common toxicities associated with ALK-TKIs are gastrointestine toxicities including nausea, vomiting and diarrhea, and the severity of these toxicities is mild [15-17]. However, physicians pay more attentions to the incidence and risk of liver toxicities associated with ALK-TKIs when administrating these drugs, although the mechanism of ALK-TKIs-related liver toxicities remains unknown [18]. Current recognition of its risk are generally from single individual clinical trial, but the sample of these studies are small and might have patient selection bias. As a result, we conduct a systematic review and meta-analysis of published data associated with ALK-TKIs to investigate the overall incidence and risk of liver toxicities with the administration of these drugs.

\section{MATERIALS AND METHODS}

\section{Clinical end point}

Three variables were separately considered such as expression of hepatotoxicity: the increase of alanine aminotransferase (ALT) and the increase of aspartate aminotransferase (AST). For each variable, we considered the increase of all grades and grade $3-4$ as the main outcomes and the analysis was conducted in order to find a significant difference between the two arms. Adverse events were defined as per version three of the National Cancer Institute's Common Terminology Criteria for Adverse Events criteria because of its use in the selected trials (NCICTC, version 3 or 4 ; http://ctep.cancer.gov). In the event a study reported high-grade but not low-grade liver toxicities, no assumption of all-grade incidence was made.

\section{Data sources}

We searched the Pubmed (data from Jan 2000 to Jan 2017), Embase (data from Jan 2000 to Jan 2017) and the Cochrane Library electronic databases. Key words were "ALK-TKIs", "ALK inhibitors", "crizotinib", "ceritinib", “alectinib", "non-small-cell lung cancer", "non-small-cell lung carcinoma", "prospective trials" and "liver toxicities". The search was limited to prospective clinical trials published in English. We also searched abstracts containing the term "ALK-TKIs" that were presented at the American Society of Clinical Oncology (ASCO) and European Society of Medical Oncology (ESMO) annual meetings from 2004 to 2017 to identify relevant studies. Additionally, we searched the clinical trial registration website (http://www.ClinicalTrials.gov) to obtain information on the registered prospective trials. Each publication was reviewed and in cases of duplicate publication only the most complete, recent, and updated report of the clinical trial was included in the metaanalysis.

\section{Study selection}

Phase I trials were excluded from analyses due to multiple dose level and limited sample sizes, and only prospective phase II/III trials evaluating ALK-TKIs in NSCLC patients with adequate data on liver toxicities were incorporated in the analysis. Clinical trials that met the following criteria were included: (1) prospective phase II or III trials involving NSCLC patients; and (2) available data regarding events or incidence of liver toxicities and sample size. If multiple publications of the same trial were retrieved or if there was a case mix between publications, only the most recent publication (and the most informative) was included.

\section{Data extraction}

Data abstraction was conducted independently by two investigators, and any discrepancy between the reviewers was resolved by consensus. For each study, the following information was extracted: first author's name, year of publication, trial phase, number of enrolled subjects, treatment arms, number of patients in treatment and controlled groups, median age, median progression-free survival, and adverse outcomes of interest (liver toxicities).

\section{Statistical analysis}

For the calculation of incidence, the number of patients with liver toxicities in ALK-TKIs group and the total number of patients receiving ALK-TKIs were extracted from the selected clinical trials; the proportion of patients with liver toxicities and 95\% confidence interval (CI) were derived for each study. To calculate relative risk (RR), patients assigned to ALK-TKIs were compared only with those assigned to control treatment in the same trial. For one study that reported zero events in the treatment or control arm, we applied the classic half-integer correction to calculate the RR and variance [19]. Betweenstudy heterogeneity was estimated using the $\chi^{2}$-based Q statistic [20]. Heterogeneity was considered statistically significant when $P$ heterogeneity $<0.1$. If heterogeneity existed, the pooled estimate calculated based on the randomeffects model was reported using the DerSimonian et al method [21]. In the absence of heterogeneity, the pooled estimate calculated based on the fixed-effects model was reported using inverse variance method. A statistical test with a $p$-value less than 0.05 was considered significant. The presence of publication bias was evaluated by using the Begg and Egger tests [22]. The Jadad scale 
was used to assess the quality of randomized controlled trials based on the reporting of the studies' methods and results [23]. And we used the Newcastle-Ottawa quality assessment scale to assess the quality of non-comparative (uncontrolled) studies. We selected items that focused on representativeness of study patients, demonstration that the outcome of interest was not present at the start of the study, adequate assessment of outcome, sufficient length of follow-up to allow outcomes to arise, and adequacy of follow-up (Supplementary Table 1). All statistical analyses were performed by using Version 2 of the Comprehensive MetaAnalysis program (Biostat, Englewood, NJ).

\section{RESULTS}

\section{Eligible studies}

A total of 210 records relevant to ALK-TKIs were identified according to the search strategy. The reasons for study exclusion were shown in Figure 1, and we finally selected 10 prospective trials, included 3 phase III [24-26] and 7 phase II trials [27-33] (Table 1). The present study was conducted based on the Preferred Reporting Items for Systematic review and Meta-Analysis (PRISMA) statement (Supplementary Table 2) [34]. A total of 1,908 patients were available for the meta-analysis. The characteristics of patients and studies were listed in Table 1. Based on the eligibility criteria of each trial, patients with impaired renal, hepatic or hematological function were excluded. All of the three randomized controlled trials were open-label controlled trials, thus had Jadad score of 3. For seven non-randomized controlled trials, the quality score was also high $(\geq 6)$ according to NOS checklists.

\section{ALT increase}

For the overall incidence analysis, only patients received ALK-TKIs alone were included. Thus, a total of 1,197 patients from ten trials were included in the analysis: all-grade ALT increase was reported in 430 out of 1,197 patients with a pooled incidence of $26.0 \%(95 \%$ CI: $17.8-36.3 \%$, Figure 2A).We then conducted sub-group analysis to investigate the incidence difference among different ALK-TKIs and found that the incidence of ALT associated with ceritinib (53.6\%, 95\%CI: 31.3-74.6\%) was significantly higher than that of alectinib (13.3\%, 95\%CI: 6.7-24.7\%) and crizotinib (26.9\%, 95\%CI: 13.4 $46.6 \%$ ). The RR (fixed effect) to develop any grade of ALT increase was 3.79 (95\% CI, 2.89-4.98; $p<0.001)$ in advanced NSCLC patients received ALK-TKIs in comparison with chemotherapy $(Q=4.26, p=0.12$; $I^{2}=53.1 \%$ ) (Figure 3A).

The incidence and risk of high-grade (grade 3-4) ALT increase was assessed in 1,374 patients, and the pooled incidence of high grade ALT increase was 9.9\%
(95\% CI, 5.6-16.7\%, Figure 2B) for ALK-TKIs. In addition, the use of ALK-TKIs in advanced NSCLC patients significantly increased the risk of developing grade 3-4 of ALT increase with RR of 8.92 (95\% CI, $4.67-17.0 ; p<0.001$, Figure 3B). There was no significant heterogeneity in the RR analysis for high-grade ALT increase $\left(Q=2.61 ; p=0.27 ; I^{2}=23.4 \%\right)$.

\section{AST increase}

For incidence of any grade of AST increase, a total of 1,211 patients were available. All grade of AST increase was reported in 366 out of 1,211 NSCLC patients treated with ALK-TKIs with a pooled incidence of $25.2 \%(95 \%$ CI, 17.7-34.7\%, Figure 4A). Sub-group analysis based on the ALT-TKIs demonstrated that the incidence of AST elevation associated with ceritinib (41.9\%, 95\% CI: $23.3-$ $63.1 \%)$ was higher than that of alectinib $(14.7 \%, 95 \% \mathrm{CI}$ : 7.1-28.2\%) and crizotinib (25\%, 95\% CI: $14.2-34.7 \%)$. The risk of developing all-grade AST increase was 3.27 (95\% CI, 2.47-4.34; $p<0.001$, Figure 5A) in advanced NSCLC patients treated with ALK-TKIs in comparison with controls.

The incidence of high-grade (grade 3-4) AST increase was assessed in 1,374 patients and the pooled incidence of high grade of AST increase was 7.0\% (95\% CI, 5.4-9.0\%, Figure 4B) for ALK-TKI. In addition, the risk of developing high-grade AST increase (fix effect) was 11.54 (95\% CI, 4.33-30.7; $p<0.001$, Figure 5B) in advanced NSCLC patients treated with ALK-TKIs in comparison with chemotherapy. There was no significant heterogeneity in the analysis for risk of all grades $\left(Q=4.22 \%, p=0.12 ; I^{2}=52.6 \%\right)$ and high-grade $\left(Q=0.23 ; p=0.89 ; I^{2}=0 \%\right)$ of AST increase.

\section{Publication bias}

We detected no significant publication biases for all grade of hepatic toxicities by using Begg's and Egger's test $(p=0.60$ and $p=0.65$ for ALT increase, $p=0.60$ and $p=0.56$ for AST increase, respectively). In addition, we did not find significant publication biases for high grades of ALT and AST increase $(p=0.60$ and $p=0.69$ for ALT increase, $p=0.60$ and $p=0.81$ for AST increase, respectively).

\section{DISCUSSION}

Due to the increased understandings of tumor biology and the signal pathways involved in lung cancer cells proliferation, several novel targeted agents that blocking dysregulated signaling pathways, such as EGFR and vascular endothelial growth factor (VEGF) pathways have been introduced. Although targeted agents are generally well tolerated in lung cancer, severe liver toxicities associated with TKIs have been reported. 
Table 1: Baseline characteristics of ten included prospective trials

\begin{tabular}{|c|c|c|c|c|c|c|c|}
\hline Authors/year & Phase & $\begin{array}{l}\text { Patients } \\
\text { enrolled }\end{array}$ & Treatment Arm & $\begin{array}{c}\text { Median } \\
\text { age }(y)\end{array}$ & $\begin{array}{l}\text { Median } \\
\text { PFS (m) }\end{array}$ & $\begin{array}{c}\text { Median } \\
\text { OS (m) }\end{array}$ & $\begin{array}{l}\text { No. for } \\
\text { analysis }\end{array}$ \\
\hline Kwak E.L. et al/2010 [27] & $\begin{array}{l}\text { Expansion } \\
\text { cohort }\end{array}$ & 82 & $\begin{array}{l}\text { Crizotinib } 250 \mathrm{mg} \\
\text { bid po }\end{array}$ & 51 & NR & NR & 82 \\
\hline Camidge D.R. et al/2012 [28] & $\begin{array}{l}\text { Expansion } \\
\text { cohort }\end{array}$ & 149 & $\begin{array}{l}\text { Crizotinib } 250 \mathrm{mg} \\
\text { bid po }\end{array}$ & 52 & 9.7 & NR & 149 \\
\hline \multirow[t]{2}{*}{ Shaw A.T. et al/2013 [24] } & III & 347 & $\begin{array}{l}\text { Crizotinib } 500 \mathrm{mg} \\
\text { bid po }\end{array}$ & 51 & 7.7 & 20.3 & 172 \\
\hline & & & Chemotherapy & 49 & 3 & 22.8 & 171 \\
\hline Shaw A.T. et al/2014a [29] & $\begin{array}{l}\text { Expansion } \\
\text { cohort }\end{array}$ & 81 & $\begin{array}{l}\text { Ceritinib } 750 \mathrm{mg} \\
\text { qd po }\end{array}$ & 53 & NR & NR & 81 \\
\hline Shaw A.T. et al/2014b [30] & $\begin{array}{l}\text { Expansion } \\
\text { cohort }\end{array}$ & 50 & $\begin{array}{l}\text { Crizotinib } 250 \mathrm{mg} \\
\text { bid po }\end{array}$ & 53 & 19.2 & NR & 50 \\
\hline \multirow[t]{2}{*}{ Solomon B.J. et al/2014 [25] } & III & 343 & $\begin{array}{l}\text { Crizotinib } 500 \mathrm{mg} \\
\text { bid po }\end{array}$ & 52 & 10.9 & NR & 171 \\
\hline & & & Chemotherapy & 54 & 7 & NR & 169 \\
\hline Shaw A.T. et al/2016 [33] & II & 87 & $\begin{array}{l}\text { Alectinib } 600 \mathrm{mg} \\
\text { bid po }\end{array}$ & 54 & NR & NR & 87 \\
\hline Kim D.W. et al/2016 [31] & $\begin{array}{l}\text { Expansion } \\
\text { cohort }\end{array}$ & 255 & $\begin{array}{l}\text { Ceritinib } 750 \mathrm{mg} \\
\text { qd po }\end{array}$ & NR & NR & NR & 255 \\
\hline Ou S.H. et al/2016 [32] & II & 138 & $\begin{array}{l}\text { Alectinib } 600 \mathrm{mg} \\
\text { bid po }\end{array}$ & 52 & 8.9 & NR & 138 \\
\hline \multirow[t]{2}{*}{ Soria J.C. et al/2017 [26] } & III & 376 & $\begin{array}{l}\text { Ceritinib } 750 \mathrm{mg} \\
\text { qd po }\end{array}$ & 55 & 16.6 & NR & 189 \\
\hline & & & Chemotherapy & 54 & 8.1 & NR & 175 \\
\hline
\end{tabular}

Abbreviations: PFS, progression-free survival; OS, overall survival; NR, not reported

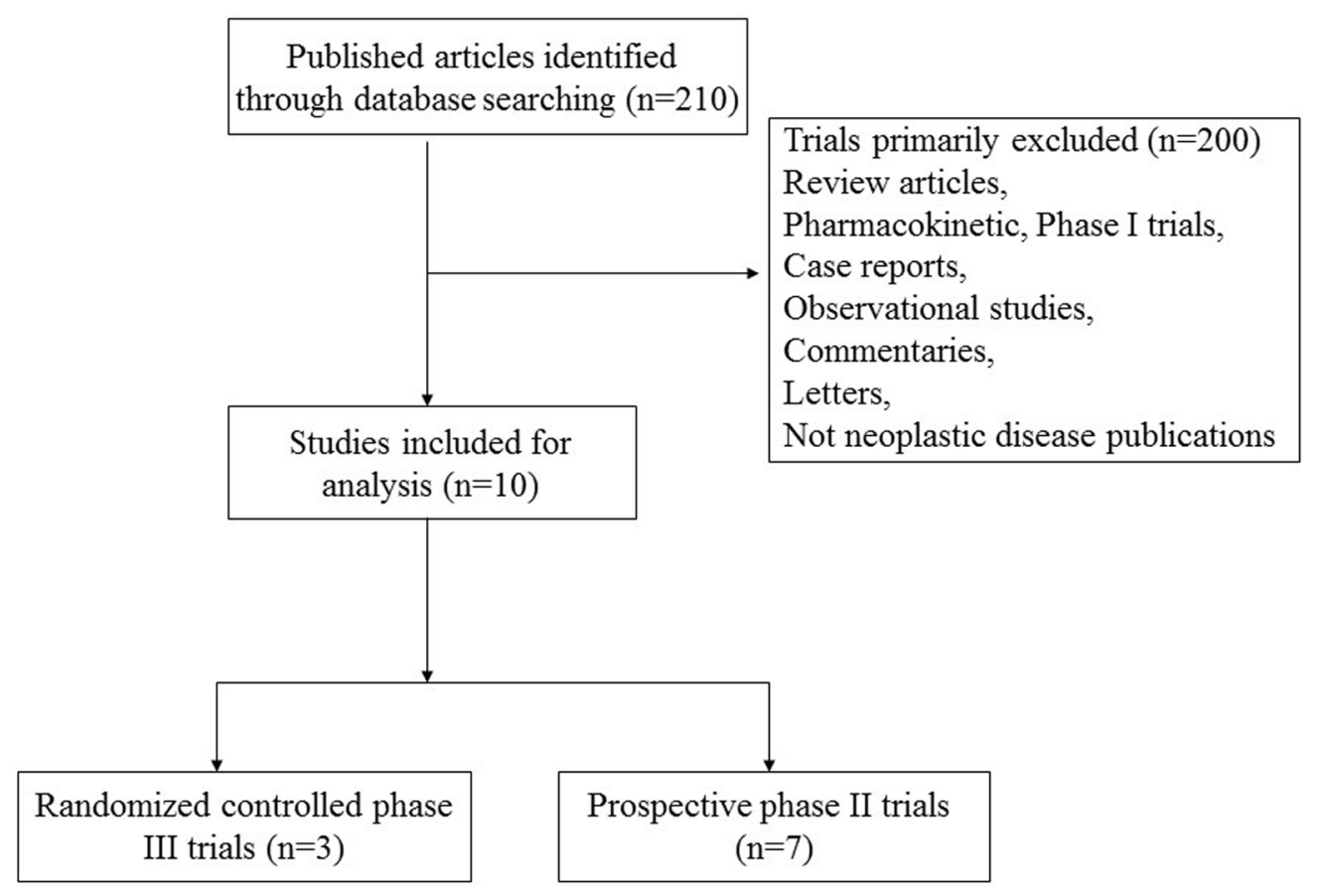

Figure 1: Flow chart of trial selection process in the meta-analysis. 
A Group by Study name

drug

alectinib

alectinib

alectinib

ceritinib

ceritinib

ceritinib

crizotinib

crizotinib

crizotinib

crizotinib

crizotinib

Overall
Statistics for each study

Event Lower Upper

rate limit limit Z-Value $p$-Value Total

Shaw A.T. et al/2016 $0.184 \quad 0.116 \quad 0.279 \quad-5.384 \quad 0.000 \quad 16 / 87$

$\begin{array}{lllllll}\text { Ou S.H. et al/2016 } & 0.094 & 0.055 & 0.155 & -7.767 & 0.000 & 13 / 138\end{array}$

$\begin{array}{lllllll}0.133 & 0.067 & 0.247 & -4.841 & 0.000 & 29 / 225\end{array}$

Kim D.W. et al/2016 $0.420 \quad 0.361 \quad 0.481 \quad-2.556 \quad 0.011107 / 255$

Soria J.C. et al/2017 $0.651 \quad 0.578 \quad 0.718 \quad 3.942 \quad 0.000 \quad 114 / 175$

$\begin{array}{llllll}0.536 & 0.313 & 0.746 & 0.307 & 0.759 & 221 / 430\end{array}$

Camidge D.R. et al/201Q.121 $0.077 \quad 0.184 \quad \begin{array}{llllll}-7.896 & 0.000 & 18 / 149\end{array}$

$\begin{array}{lllllll}\text { Shaw A.T. et al/2013 } & 0.459 & 0.386 & 0.534 & -1.066 & 0.286 & 79 / 172\end{array}$

Shaw A.T. et al/2014b $0.140 \quad 0.068 \quad 0.266 \quad-4.454 \quad 0.000 \quad 7 / 50$

Solomon B.J. et al/2014.444 $0.372 \quad 0.520 \quad-1.450 \quad 0.147 \quad 76 / 171$

$\begin{array}{llllll}0.269 & 0.134 & 0.466 & -2.270 & 0.023 & 180 / 542\end{array}$

$\begin{array}{lllll}0.260 & 0.178 & 0.363 & -4.220 & 0.000430 / 1197\end{array}$

B Study name

\begin{tabular}{|c|c|c|c|c|c|c|}
\hline & $\begin{array}{c}\text { Event } \\
\text { rate }\end{array}$ & $\begin{array}{l}\text { Lower } \\
\text { limit }\end{array}$ & $\begin{array}{l}\text { Upper } \\
\text { limit }\end{array}$ & Z-Value & $\mathrm{p}$-Value & Tot \\
\hline Nak E.L. et al/2010 & 1 & 026 & 0.138 & -5.925 & .000 & $5 / 82$ \\
\hline D.R. et al/2012 & 20 & .018 & 0.087 & -7.610 & 0.000 & $6 / 149$ \\
\hline haw A.T. et al/2013 & 0.087 & 0.053 & 0.140 & -8.689 & 0.000 & $15 / 172$ \\
\hline haw & 0.235 & 155 & 339 & -4.510 & 0.000 & $19 / 81$ \\
\hline haw & 0.040 & .010 & 0.146 & -4.404 & 0.000 & $2 / 50$ \\
\hline$/ 2014$ & 40.099 & 0.063 & 0.154 & -8.623 & 0.000 & $17 / 171$ \\
\hline hav & 0.057 & 0.024 & 131 & -6.073 & 0.000 & $5 / 87$ \\
\hline $\operatorname{im}$ & 0.286 & 0.234 & 0.345 & -6.594 & 0.000 & $73 / 255$ \\
\hline Ou S.I & 0.014 & 0.004 & 0.056 & -5.924 & 0.000 & $2 / 138$ \\
\hline Soria J.C. et al/2017 & 0.307 & 0.245 & 0.376 & -5.166 & 0.000 & $58 / 189$ \\
\hline overall & 0.099 & 0.056 & 0.167 & -7.164 & 0.000 & $202 / 137$ \\
\hline
\end{tabular}

Event rate and $95 \% \mathrm{Cl}$

ALL-grade ALT elevation

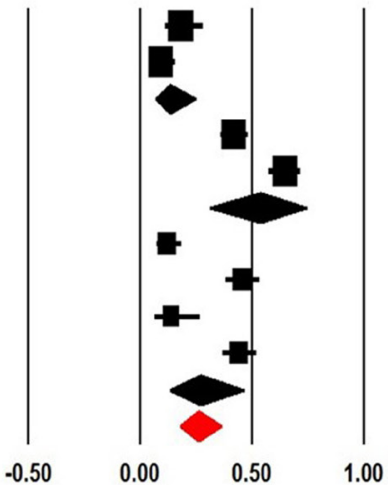

Event rate and $95 \% \mathrm{Cl}$

high-grade ALT elevation

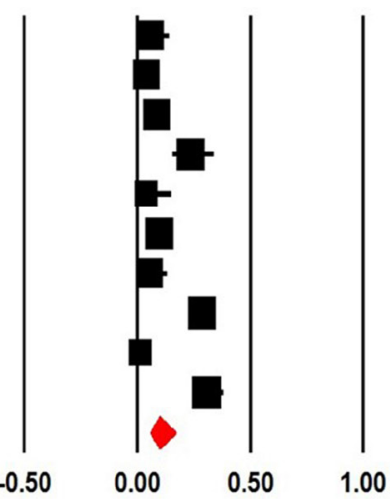

Figure 2: Forest plot for meta-analysis of incidence of all-grade and high-grade ALT elevation in NSCLC patients assigned ALK-TKIs.

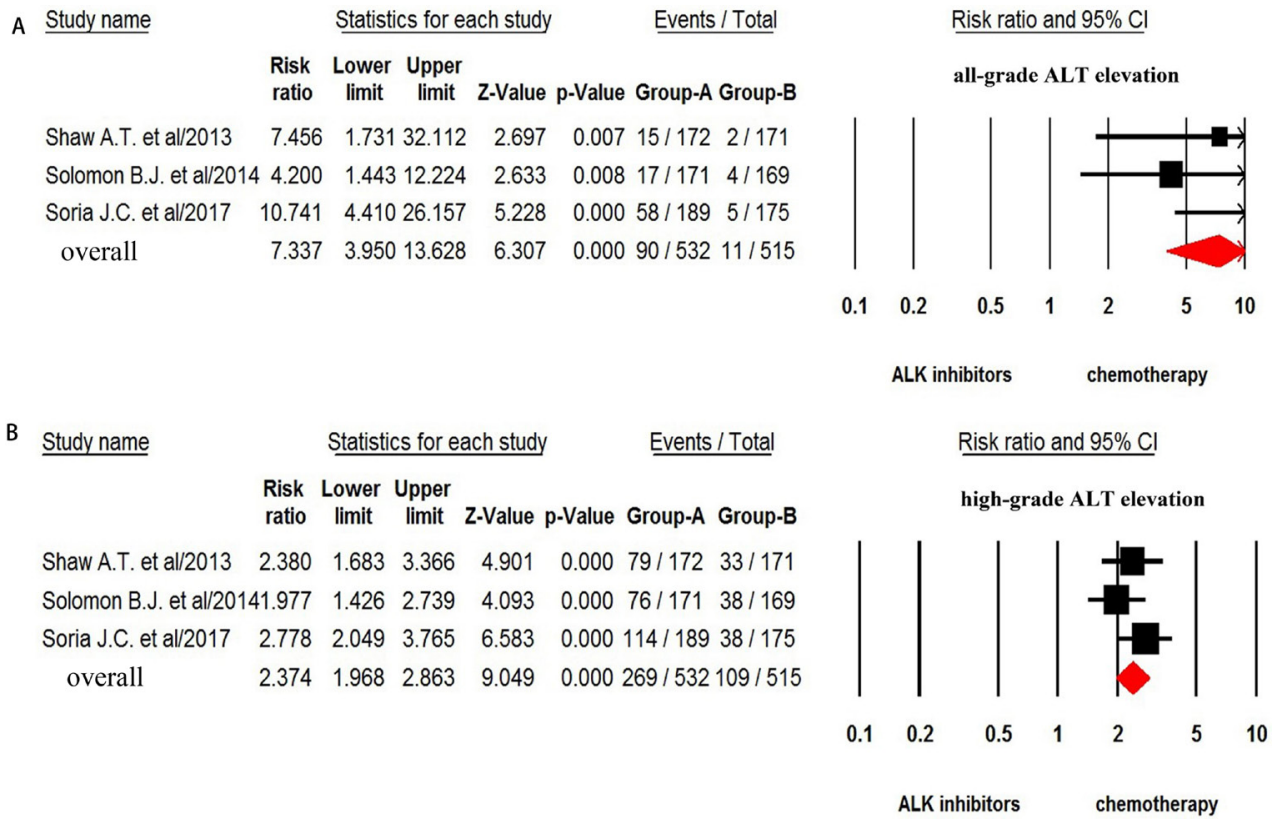

Figure 3: Relative risk of ALK-TKIs-associated all-grade and high-grade ALT elevation versus control from randomized controlled trials. 


\begin{tabular}{|c|c|c|c|c|c|c|c|}
\hline \multirow[t]{2}{*}{$A$} & \multirow[t]{2}{*}{ Study name } & \multicolumn{6}{|c|}{ Statistics for each study } \\
\hline & & $\begin{array}{c}\text { Event } \\
\text { rate }\end{array}$ & $\begin{array}{c}\text { Lower } \\
\text { limit }\end{array}$ & $\begin{array}{c}\text { Upper } \\
\text { limit }\end{array}$ & z-Value & p-Value & Total \\
\hline alectinib & Shaw A.T. et al/2016 & 0.207 & 0.134 & 0.305 & -5.077 & 0.000 & $18 / 87$ \\
\hline alectinib & Ou S.H. et al/2016 & 0.101 & 0.061 & 0.164 & -7.736 & 0.000 & $14 / 138$ \\
\hline alectinib & & 0.147 & 0.071 & 0.282 & -4.196 & 0.000 & $32 / 225$ \\
\hline ceritinib & Kim D.W. et al/2016 & 0.318 & 0.263 & 0.377 & -5.684 & 0.000 & $81 / 255$ \\
\hline ceritinib & Soria J.C. et al/2017 & 0.529 & 0.458 & 0.599 & 0.800 & 0.424 & $+100 / 189$ \\
\hline ceritinib & & 0.419 & 0.233 & 0.631 & -0.740 & 0.460 & $181 / 444$ \\
\hline crizotinib & Camidge D.R. et al/20 & 016.101 & 0.062 & 0.160 & -8.043 & 0.000 & ) $15 / 149$ \\
\hline crizotinib & Shaw A.T. et al/2013 & 0.384 & 0.314 & 0.458 & -3.022 & 0.003 & $66 / 172$ \\
\hline crizotinib & Shaw A.T. et al/2014b & 0.220 & 0.126 & 0.355 & -3.707 & 0.000 & $11 / 50$ \\
\hline crizotinib & Solomon B.J. et al/201 & 14.357 & 0.289 & 0.431 & -3.693 & 0.000 & $61 / 171$ \\
\hline crizotinib & & 0.250 & 0.142 & 0.402 & -3.068 & 0.002 & $153 / 542$ \\
\hline Overall & & 0.252 & 0.177 & 0.347 & -4.693 & 0.000 & $366 / 1211$ \\
\hline
\end{tabular}

B Group by $\frac{\text { Study name }}{\text { drug }}$

Statistics for each study

Event Lower Upper

rate limit limit $z$-Value $p$-Value Total

$\begin{array}{llllllll}\text { alectinib Shaw A.T. et al/2016 } & 0.046 & 0.017 & 0.116 & -5.924 & 0.000 & 4 / 87\end{array}$

$\begin{array}{llllllll}\text { alectinib } \quad \text { Ou S.H. et al/2016 } & 0.014 & 0.004 & 0.056 & -5.924 & 0.000 & 2 / 138\end{array}$

alectinib $\quad \begin{array}{lllllll}0.029 & 0.009 & 0.085 & -6.028 & 0.000 & 6 / 225\end{array}$

$\begin{array}{lllllll}\text { ceritinib Shaw A.T. et al/2014a } & 0.123 & 0.068 & 0.214 & -5.803 & 0.000 & 10 / 81\end{array}$

$\begin{array}{llllllll}\text { ceritinib Kim D.W. et al/2016 } & 0.098 & 0.067 & 0.141 & -10.538 & 0.000 & 25 / 255\end{array}$

$\begin{array}{lllllll}\text { ceritinib Soria J.C. et al/2017 } & 0.169 & 0.122 & 0.230 & -8.200 & 0.000 & 32 / 189\end{array}$

$\begin{array}{lllllll}\text { ceritinib } & 0.129 & 0.088 & 0.184 & -8.880 & 0.000 & 67 / 525\end{array}$

$\begin{array}{llllllll}\text { crizotinib Kwak E.L. et al/2010 } & 0.061 & 0.026 & 0.138 & -5.925 & 0.000 & 5 / 82\end{array}$

$\begin{array}{lllllll}\text { crizotinib Camidge D.R. et al/2018.034 } & 0.014 & 0.078 & -7.387 & 0.000 & 5 / 149\end{array}$

$\begin{array}{llllllll}\text { crizotinib Shaw A.T. et al/2013 } & 0.047 & 0.023 & 0.090 & -8.342 & 0.000 & 8 / 172\end{array}$

crizotinib Shaw A.T. et al/2014b $0.020 \quad 0.003 \quad 0.129 \quad-3.853 \quad 0.000 \quad 1 / 50$

$\begin{array}{lllllll}\text { crizotinib Solomon B.J. et al/2014.053 } & 0.028 & 0.098 & -8.440 & 0.000 & 9 / 171\end{array}$

$\begin{array}{lllllll}\text { crizotinib } & 0.046 & 0.032 & 0.066 & -15.605 & 0.000 & 28 / 624\end{array}$

Overall

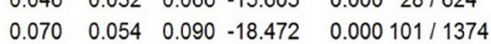

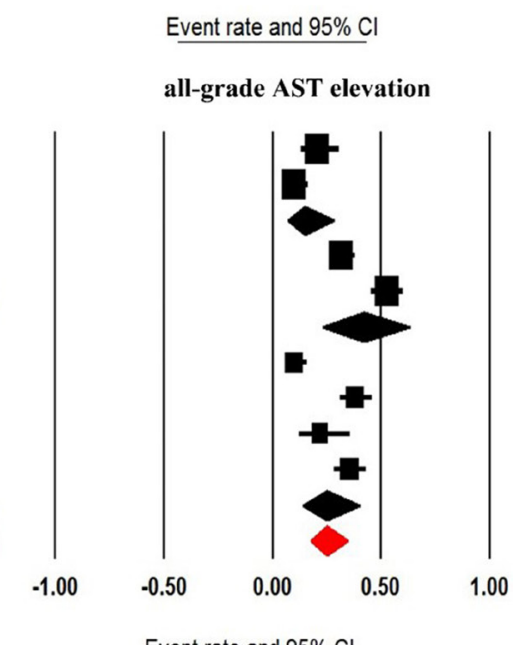

Event rate and $95 \% \mathrm{Cl}$

high-grade AST elevation

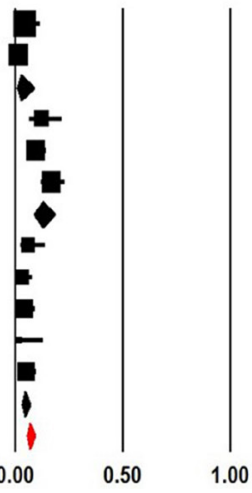

Figure 4: Forest plot for meta-analysis of incidence of all-grade and high-grade AST elevation in NSCLC patients assigned ALK-TKIs.

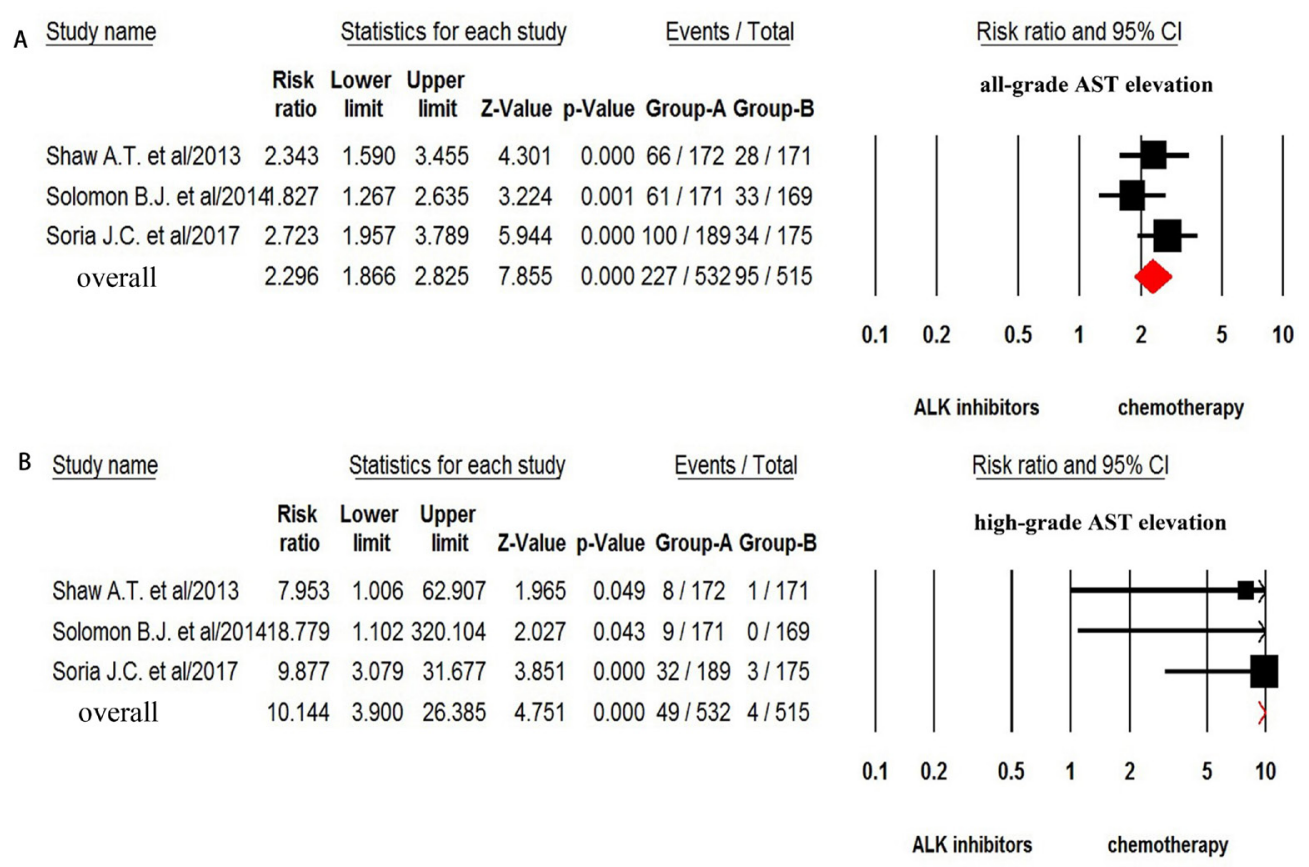

Figure 5: Relative risk of ALK-TKIs-associated all-grade and high-grade AST elevation versus control from randomized controlled trials. 
Indeed, two previously published meta-analyses find that the use of VEGF receptor-tyrosine kinase inhibitors significantly increases the risk of developing liver toxicities $[35,36]$. However, the overall incidence and risk of liver toxicities associated with ALK-TKIs remains undetermined. A total of 1908 advanced NSCLC patients from 10 prospective trials are included for analysis, and our study, for the first-time, shows that the use of ALKTKIs significantly increases the risk of developing liver toxicity. The summary incidences of all-grade ALT and AST increase were $26.0 \%$ (95\% CI: $17.8-36.3$ ), and $25.2 \%$ (95\% CI, 17.7-34.7), respectively with 9.9\% (95\% CI, 5.6-16.7), and 7.0\% (95\% CI, 5.4-9.0) being highgrade, respectively. Compared to chemotherapy alone, a statistical increase risk of developing all-grade ALT and AST elevations (RR 3.79 and 3.27, respectively) is found in advanced NSCLC patients treated with ALK-TKIs. Additionally, increased risk of developing high-grade ALT and AST elevations are also observed (RR 8.92 and 11.54 , respectively) in patients exposed to ALK-TKIs. The findings of the present study will help physicians to fully know the incidence and risk of drug-induced liver toxicities associated with ALK-TKIs in advanced NSCLC patients. Recently, two ALK-TKIs, crizotinib and ceritinib, have been approved for the treatment of advanced ALKpositive NSCLC patients, thus the use of these drugs is anticipated to be increased in anti-cancer treatment and clinical studies. Based on our findings, the following methods might be considered to reduce the potential risk of liver toxicities associated with ALK-TKIs: clinicians should monitor patients during the course of ALK-TKIs treatment and should provide appropriate intervention to reduce morbidity and mortality related to liver damage.

Drug-induced hepatotoxicity is one of the major concerns in clinical practice, because drug-induced liver injury is the most common reason for withdrawal of an approved drug and study terminations. There are several theories for the pathogenesis of drug-induced liver toxicities have been recommended, including immune mediated response, mitochondrial dysfunction and variations in host metabolic response. However, the specific mechanism of ALK-TKIs induced hepatic toxicity remains undetermined, further studies are recommended to address this issues.

Currently, there are no specific guidelines to monitor and manage ALK-TKIs related liver toxicities. According to the experiences from clinical trials, baseline liver function of each patient should be assessed before treatment, and liver function should be monitored every two weeks during the first two months, then monthly and as clinically indicated [18]. For patients with baseline moderate hepatic impairment, a reduced starting dose of ALK-TKIs is recommended. And these drugs should not be used for the treatment of patients with severe hepatic impairment. The majority of susceptible patients will experience liver enzyme elevations in the first few months of drug exposure, and these liver enzyme will return to baseline levels after treatment interruption. For the most of included trials in the present study, dose interruptions or discontinuations are recommended for patients with a raised transaminase levels. For patients with severe aminotransferase elevations, ALK-TKIs should be held until return to pretreatment levels. Then, ALK-TKIs could be resumed at reduced dose.

It should be noted that the present study has several limitations. Firstly, these included trials are performed at various institutions, and there might have potential bias in reported incidences of liver function abnormalities. Second, ALT, AST, and bilirubin elevation represents liver function injury, the sensitivity or specificity of these tests are limited. Thirdly, our study is a meta-analysis of published data, thus individual patient data could not be available, although previous research demonstrate that trial level and patient level meta-analyses yield similar results. Finally, only articles published in English are included for analysis in the present study, which might create some selection bias.

\section{CONCLUSIONS}

In summary, our study has demonstrated that the use of ALK-TKIs significantly increased the incidence and risk of developing all-grade and high-grade hepatotoxicity. Clinicians should clearly recognize the risks and benefits from ALK-TKIs treatment in advanced NSCLC patients, and provide appropriately monitoring of serum transaminases. Additionally, more trials are needed to assess the potential predictive factors for liver toxicities associated with ALK-TKIs treatment in order to avoid premature drug discontinuation.

\section{CONFLICTS OF INTEREST}

All authors declare that they have no potential conflicts of interests.

\section{FUNDING}

None.

\section{REFERENCES}

1. Siegel R, Naishadham D, Jemal A. Cancer statistics, 2012. CA Cancer J Clin. 2012; 62:10-29.

2. Iacono D, Chiari R, Metro G, Bennati C, Bellezza G, Cenci M, Ricciuti B, Sidoni A, Baglivo S, Minotti V, Crinò L. Future options for ALK-positive non-small cell lung cancer. Lung Cancer. 2015; 87:211-219.

3. Peters S, Taron M, Bubendorf L, Blackhall F, Stahel R. Treatment and detection of ALK-rearranged NSCLC. Lung Cancer. 2013; 81:145-154. 
4. Blakely C, Jahan T. Emerging antiangiogenic therapies for non-small-cell lung cancer. Expert Rev Anticancer Ther. 2011; 11:1607-1618.

5. Maione P, Rossi A, Bareschino MA, Sacco PC, Schettino C, Falanga M, Barbato V, Ambrosio R, Gridelli C. Factors driving the choice of the best second-line treatment of advanced NSCLC. Rev Recent Clin Trials. 2011; 6:44-51.

6. Lee DH. Treatments for EGFR-mutant non-small cell lung cancer (NSCLC): The road to a success, paved with failures. Pharmacology \& therapeutics. 2017; 174:1-21.

7. Stinchcombe TE. The Use of EGFR Tyrosine Kinase Inhibitors in EGFR Wild-Type Non-Small-Cell Lung Cancer. Curr Treat Options Oncol. 2016; 17:18.

8. Maemondo M, Inoue A, Kobayashi K, Sugawara S, Oizumi S, Isobe H, Gemma A, Harada M, Yoshizawa H, Kinoshita I, Fujita Y, Okinaga S, Hirano H, et al. Gefitinib or chemotherapy for non-small-cell lung cancer with mutated EGFR. N Engl J Med. 2010; 362:2380-2388.

9. Schuler M, Yang JC, Park K, Kim JH, Bennouna J, Chen YM, Chouaid C, De Marinis F, Feng JF, Grossi F, Kim DW, Liu X, $\mathrm{Lu} \mathrm{S}$, et al. Afatinib beyond progression in patients with nonsmall-cell lung cancer following chemotherapy, erlotinib/ gefitinib and afatinib: phase III randomized LUX-Lung 5 trial. Ann Oncol. 2016; 27:417-423.

10. Peters S, Stahel RA, Dafni U, Ponce Aix S, Massuti B, Gautschi O, Coate L, Lopez Martin A, van Heemst R, Berghmans T, Meldgaard P, Cobo Dols M, Garde Noguera J, et al. Randomized Phase III Trial of Erlotinib versus Docetaxel in Patients with Advanced Squamous Cell Non-Small Cell Lung Cancer Failing First-Line Platinum-Based Doublet Chemotherapy Stratified by VeriStrat Good versus VeriStrat Poor. The European Thoracic Oncology Platform (ETOP) EMPHASIS-lung Trial. J Thorac Oncol. 2017; 12:752-762.

11. Toyokawa G, Seto T. ALK inhibitors: what is the best way to treat patients with ALK+ non-small-cell lung cancer? Clin Lung Cancer. 2014; 15:313-319.

12. Gridelli C, Peters S, Sgambato A, Casaluce F, Adjei AA, Ciardiello F. ALK inhibitors in the treatment of advanced NSCLC. Cancer Treat Rev. 2014; 40:300-306.

13. Kazandjian D, Blumenthal GM, Chen HY, He K, Patel M, Justice R, Keegan P, Pazdur R. FDA approval summary: crizotinib for the treatment of metastatic non-small cell lung cancer with anaplastic lymphoma kinase rearrangements. Oncologist. 2014; 19:e5-11.

14. Khozin S, Blumenthal GM, Zhang L, Tang S, Brower M, Fox E, Helms W, Leong R, Song P, Pan Y, Liu Q, Zhao P, Zhao H, et al. FDA approval: ceritinib for the treatment of metastatic anaplastic lymphoma kinase-positive non-small cell lung cancer. Clin Cancer Res. 2015; 21:2436-2439.

15. Loong HH, Mok K, Leung LK, Mok TS. Crizotinib in the management of advanced-stage non-small-cell lung cancer. Future Oncol. 2015; 11:735-745.

16. Cameron L, Solomon B. New Treatment Options for ALK-Rearranged Non-Small Cell Lung Cancer. Curr Treat Options Oncol. 2015; 16:49.
17. Solomon B, Wilner KD, Shaw AT. Current status of targeted therapy for anaplastic lymphoma kinase-rearranged nonsmall cell lung cancer. Clin Pharmacol Ther. 2014; 95:15-23.

18. Rothenstein JM, Letarte N. Managing treatment-related adverse events associated with Alk inhibitors. Curr Oncol. $2014 ; 21: 19-26$.

19. Choueiri TK, Schutz FA, Je Y, Rosenberg JE, Bellmunt J. Risk of arterial thromboembolic events with sunitinib and sorafenib: a systematic review and meta-analysis of clinical trials. J Clin Oncol. 2010; 28:2280-2285.

20. Zintzaras E, Ioannidis JP. Heterogeneity testing in metaanalysis of genome searches. Genet Epidemiol. 2005; 28:123-137.

21. DerSimonian R, Laird N. Meta-analysis in clinical trials. Controlled clinical trials. 1986; 7:177-188.

22. Sterne JA, Gavaghan D, Egger M. Publication and related bias in meta-analysis: power of statistical tests and prevalence in the literature. J Clin Epidemiol. 2000; 53:1119-1129.

23. Moher D, Pham B, Jones A, Cook DJ, Jadad AR, Moher M, Tugwell P, Klassen TP. Does quality of reports of randomised trials affect estimates of intervention efficacy reported in meta-analyses? Lancet. 1998; 352:609-613.

24. Shaw AT, Kim DW, Nakagawa K, Seto T, Crino L, Ahn MJ, De Pas T, Besse B, Solomon BJ, Blackhall F, Wu YL, Thomas M, O'Byrne KJ, et al. Crizotinib versus chemotherapy in advanced ALK-positive lung cancer. N Engl J Med. 2013; 368:2385-2394.

25. Solomon BJ, Mok T, Kim DW, Wu YL, Nakagawa K, Mekhail T, Felip E, Cappuzzo F, Paolini J, Usari T, Iyer S, Reisman A, Wilner KD, et al. First-line crizotinib versus chemotherapy in ALK-positive lung cancer. N Engl J Med. 2014; 371:2167-2177.

26. Soria JC, Tan DS, Chiari R, Wu YL, Paz-Ares L, Wolf J, Geater SL, Orlov S, Cortinovis D, Yu CJ, Hochmair M, Cortot AB, Tsai CM, et al. First-line ceritinib versus platinum-based chemotherapy in advanced ALK-rearranged non-small-cell lung cancer (ASCEND-4): a randomised, open-label, phase 3 study. Lancet. 2017; 389:917-929.

27. Kwak EL, Bang YJ, Camidge DR, Shaw AT, Solomon B, Maki RG, Ou SH, Dezube BJ, Janne PA, Costa DB, VarellaGarcia M, Kim WH, Lynch TJ, et al. Anaplastic lymphoma kinase inhibition in non-small-cell lung cancer. N Engl J Med. 2010; 363:1693-1703.

28. Camidge DR, Bang YJ, Kwak EL, Iafrate AJ, VarellaGarcia M, Fox SB, Riely GJ, Solomon B, Ou SH, Kim DW, Salgia R, Fidias P, Engelman JA, et al. Activity and safety of crizotinib in patients with ALK-positive non-small-cell lung cancer: updated results from a phase 1 study. Lancet Oncol. 2012; 13:1011-1019.

29. Shaw AT, Kim DW, Mehra R, Tan DS, Felip E, Chow LQ, Camidge DR, Vansteenkiste J, Sharma S, De Pas T, Riely GJ, Solomon BJ, Wolf J, et al. Ceritinib in ALK-rearranged non-small-cell lung cancer. N Engl J Med. 2014; 370: 1189-1197. 
30. Shaw AT, Ou SH, Bang YJ, Camidge DR, Solomon BJ, Salgia R, Riely GJ, Varella-Garcia M, Shapiro GI, Costa DB, Doebele RC, Le LP, Zheng Z, et al. Crizotinib in ROS1-rearranged non-small-cell lung cancer. N Engl J Med. 2014; 371:1963-1971.

31. Kim DW, Mehra R, Tan DS, Felip E, Chow LQ, Camidge DR, Vansteenkiste J, Sharma S, De Pas T, Riely GJ, Solomon BJ, Wolf J, Thomas M, et al. Activity and safety of ceritinib in patients with ALK-rearranged nonsmall-cell lung cancer (ASCEND-1): updated results from the multicentre, open-label, phase 1 trial. Lancet Oncol. 2016; 17:452-463.

32. Ou SH, Ahn JS, De Petris L, Govindan R, Yang JC, Hughes B, Lena H, Moro-Sibilot D, Bearz A, Ramirez SV, Mekhail T, Spira A, Bordogna W, et al. Alectinib in Crizotinib-Refractory ALK-Rearranged Non-Small-Cell Lung Cancer: A Phase II Global Study. J Clin Oncol. 2016; 34:661-668.
33. Shaw AT, Gandhi L, Gadgeel S, Riely GJ, Cetnar J, West H, Camidge DR, Socinski MA, Chiappori A, Mekhail T, Chao $\mathrm{BH}$, Borghaei H, Gold KA, et al. Alectinib in ALK-positive, crizotinib-resistant, non-small-cell lung cancer: a singlegroup, multicentre, phase 2 trial. Lancet Oncol. 2016; 17:234-242.

34. Moher D, Cook DJ, Eastwood S, Olkin I, Rennie D, Stroup DF. Improving the quality of reports of metaanalyses of randomised controlled trials: the QUOROM statement. Quality of Reporting of Meta-analyses. Lancet. 1999; 354:1896-1900.

35. Teo YL, Ho HK, Chan A. Risk of tyrosine kinase inhibitorsinduced hepatotoxicity in cancer patients: a meta-analysis. Cancer Treat Rev. 2013; 39:199-206.

36. Kapadia S, Hapani S, Choueiri TK, Wu S. Risk of liver toxicity with the angiogenesis inhibitor pazopanib in cancer patients. Acta Oncol. 2013; 52:1202-12. 